\title{
Glucosamine and caveat emptor
}

\author{
Friedrich C. Luft
}

Published online: 23 October 2013

(C) Springer-Verlag Berlin Heidelberg 2013

Glucosamine is an abundant monosaccharide and a prominent precursor in the biochemical synthesis of glycosylated proteins and lipids (Fig. 1a). Glucosamine is also a structural part of the polysaccharides chitosan and chitin, which compose the exoskeletons of crustaceans and other arthropods, as well as the cell walls of fungi and many higher organisms. The hydrolysis of crustacean exoskeletons or, less commonly, by fermentation of a grain such as corn or wheat, is used to produce glucosamine commercially. In the USA, glucosamine is one of the most common non-vitamin, nonmineral, dietary supplements used by adults and is considered a "dietary supplement" (food) rather than a drug. To market any dietary supplement as a treatment for any disease or condition is illegal in the USA. The US National Institutes of Health funded a 24-week, 12.5 million-dollar multicenter clinical trial, the Glucosamine/Chondroitin Arthritis Intervention Trial (GAIT), to study the effect of chondroitin sulfate, glucosamine hydrochloride, chondroitin/glucosamine in combination, and celecoxib as a treatment for knee pain in two groups of patients with osteoarthritis of the knee. The GAIT study could show no effectiveness for glucosamine [1]. Cochrane reviews, other meta-analyses, and other studies reached similar conclusions [2]. Thus, a healthy dose of skepticism (caveat emptor) is warranted when inspecting the salubrious effects of glucosamine on health.

The glucosamine focus has been on osteoarthritis where loss of collagen surfaces is the major issue but fibrosis and scarring also play a role. Chronic fibrosis also involves the kidney. Indeed, urinary tract obstruction leads to renal fibrosis and the unilateral ureteral obstruction (UUO) model is a

F. C. Luft $(\bowtie)$

Experimental and Clinical Research Center, Charité Medical Faculty and the Max-Delbrück Center for Molecular Medicine,

Lindenbergerweg 80, 13125 Berlin, Germany

e-mail: luft@charite.de favorite of investigators, since the opposite kidney is an ideal non-obstructed control. Fibrosis and scarring are complicated conditions involving a host of pathways; however, the transforming growth factor- $\beta$ (TGF- $\beta$ ) is very commonly implicated [3]. Inhibiting TGF- $\beta 1$ to avoid fibrosis in the kidney has been discussed for 25 years [4]. Unfortunately, translating laboratory findings to the clinical arena has not been very successful.

In an earlier study [5], investigators from the same laboratory as the current report observed that inhibiting the $N$-linked glycosylation process impedes binding of TGF- $\beta 1$ to the T $\beta$ RII receptor complex and thereby render cells resistant to TGF- $\beta$ signaling (Fig. 1b). The human embryonic kidney-293 cell line exhibited reduced TGF- $\beta$ signaling when either treated with tunicamycin that inhibits $N$-linked glycosylation or another endoplasmic reticulum inhibitor. The authors reported that defective $N$-linked glycosylation prevented T $\beta$ RII proteins from being transported to the cell surface and thereby argued that $N$-linked glycosylation is essential for the successful cell surface transportation of the T $\beta$ RII receptor complex. Park and colleagues now used the UUO model to put glucosamine and $N$-linked glycosylation of T $\beta$ RII to the test in vitro [6].

The UUO model is extremely reproducible and features intense fibrosis. Male C57BL/6 mice were studied. The authors subjected the mice to vehicle and three incremental doses $(20-60 \mathrm{mg} / \mathrm{kg})$ of daily intraperitoneal glucosamine hydrochloride. Park et al. found that glucosamine reduced interstitial fibrosis particularly at the 40 and $60 \mathrm{mg} / \mathrm{kg} /$ day doses [6]. They next observed that $\alpha$-smooth muscle actin, a product of matrix-producing fibroblasts, was reduced, as were fibronectin and collagen I. The authors then inspected a renal tubular epithelial cell line (HKC-8). The cells were treated with $5 \mathrm{mM}$ glucosamine and were thereafter incubated with TGF- $\beta 1$. In these cells, glucosamine suppressed TGF- $\beta 1$ induced collagen I and fibronectin production. Park et al. next 
a
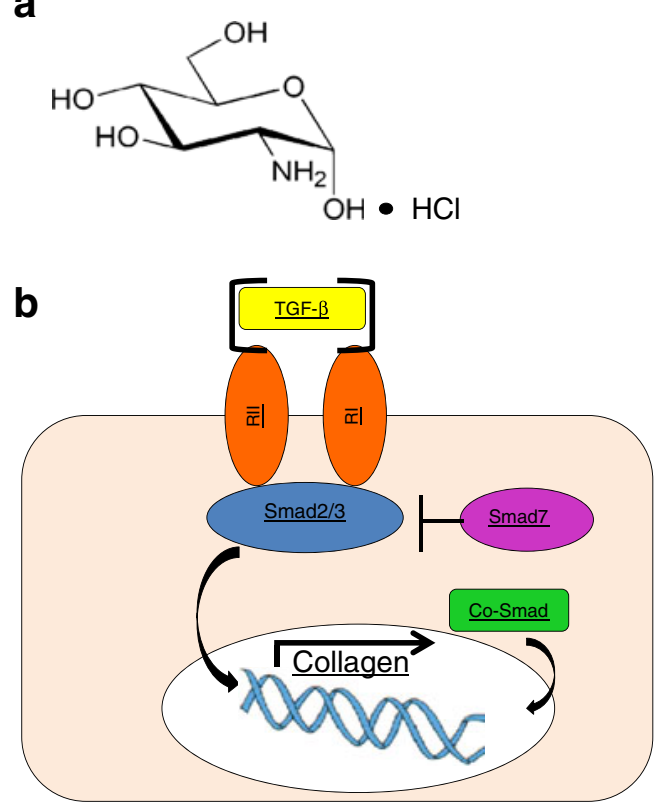

Fig. 1 a Structure of glucosamine hydrochloride b Greatly oversimplified view of TGF- $\beta$ signaling including the T $\beta$ RII-T $\beta$ RI signaling setup

tested whether or not glucosamine influenced TGF- $\beta 1$ signaling in the obstructed kidney in the UUO model [6]. They analyzed phosphorylation of Smad3, a downstream signaling molecule. Glucosamine seemed to suppress TGF- $\beta 1$ signaling pathways in vitro and in vivo.

TGF- $\beta$ family proteins are dimeric polypeptides that have vital roles in regulating cell growth and differentiation (Fig. 1b). They signal by assembling a receptor heterotetramer composed of two T $\beta$ RI/T $\beta$ RII heterodimers [7]. The authors' earlier work suggested that the sensitivity of T $\beta$ RII to TGF- $\beta$ was related to $N$-glycosylation of T $\beta$ RII [5]. Park et al. next went back to the HKC- 8 cells and transfected the cells with T $\beta$ RII [6]. Glucosamine treatment resulted in impaired $N$ glycosylation of $\mathrm{T} \beta \mathrm{RII}$ and reduced $\mathrm{Smad} 2 / 3$ phosphorylation in these cells. The authors next tested HeLa cells and observed that glucosamine-treated cells were not able to successfully transport T $\beta$ RII to the cell surface. This phenomenon was also tested in HKC-8 cells on a large scale using flow cytometry. Park et al. argued that glucosamine impedes $N$-glycosylation of T $\beta$ RII, thereby inhibiting cell surface transport of T $\beta$ RII, blocking TGF- $\beta$ signaling, an important mediator of fibrosis in the kidney.

Should we commence with trials of glucosamine for renal fibrosis related to urinary tract obstruction or other conditions? One confounding variable is the correctness of the UUO model in terms of the primary role of myofibroblasts and TGF- $\beta 1$. A recent review supports the interpretation of Park et al. [6] and other observers [8]. However, what if this view is oversimplified or not correct? Recent findings indicate that collagen-producing bone marrow-derived cells (fibrocytes) are involved in the UUO model rather than locally derived myofibroblasts [9]. Also not shown is evidence that glucosamine could affect $N$-glycosylation of T $\beta$ RII in patients. $N$-glycosylation is a universally important process and its inhibition might not be healthy. Park et al. observe that the LD50 of oral glucosamine in animals is approximately $8,000 \mathrm{mg} / \mathrm{kg}$ with no adverse effects at $2,700 \mathrm{mg} / \mathrm{kg}$ for 12 months. Humans can tolerate $184 \mathrm{mg} / \mathrm{kg} /$ day of glucosamine without side effects. Perhaps harvesting cells from such persons and controls, while testing for $\mathrm{N}$ glycosylation of T $\beta$ RII would be a worthwhile proof-ofconcept experiment.

Respectfully,

Friedrich C. Luft

\section{References}

1. Sawitzke AD, Shi H, Finco MF, Dunlop DD, Harris CL, Singer NG, Bradley JD, Silver D, Jackson CG, Lane NE et al (2010) Clinical efficacy and safety of glucosamine, chondroitin sulphate, their combination, celecoxib or placebo taken to treat osteoarthritis of the knee: 2-year results from GAIT. Ann Rheum Dis 69:1459-1464

2. Dworkin RH, Peirce-Sandner S, Turk DC, McDermott MP, Gibofsky A, Simon LS, Farrar JT, Katz NP (2011) Outcome measures in placebo-controlled trials of osteoarthritis: responsiveness to treatment effects in the REPORT database. Osteoarthr Cartil 19:483-492

3. Loeffler I, Wolf G (2013) Transforming growth factor- $\beta$ and the progression of renal disease. Nephrol Dial Transplant. doi:10.1093/ ndt/gft267

4. Border WA, Okuda S, Languino LR, Sporn MB, Ruoslahti E (1990) Suppression of experimental glomerulonephritis by antiserum against transforming growth factor beta-1. Nature 346:371-374

5. Kim YW, Park J, Lee HJ, Lee SY, Kim SJ (2012) TGF- $\beta$ sensitivity is determined by $\mathrm{N}$-linked glycosylation of the type II TGF- $\beta$ receptor. Biochem J 445(3):403-411

6. Park J, Lee SY, Ooshima A, Yang KM, Kang JM, Kim YW, Kim J (2013) Glucosamine hydrochloride exerts a protective effect against unilateral ureteral obstruction-induced renal fibrosis by attenuating TGF-b signaling. J Mol Med. doi:10.1007/s00109-013-1086-1

7. Huang T, David L, Mendoza V, Yang Y, Villarreal M, De K, Sun L, Fang X, López-Casillas F, Wrana JL et al (2011) TGF- $\beta$ signaling is mediated by two autonomously functioning T $\beta$ RI:T $\beta$ RII pairs. EMBO J 30:1263-1276

8. Samarakoon R, Overstreet JM, Higgins SP, Higgins PJ (2012) TGF$\beta 1 \rightarrow \mathrm{SMAD} / \mathrm{p} 53 / \mathrm{USF} 2 \rightarrow$ PAI-1 transcriptional axis in ureteral obstruction-induced renal fibrosis. Cell Tissue Res 347(1):117-128

9. Reich B, Schmidbauer K, Rodriguez Gomez M, Johannes Hermann F, Göbel N, Brühl H, Ketelsen I, Talke Y, Mack M (2013) Fibrocytes develop outside the kidney but contribute to renal fibrosis in a mouse model. Kidney Int 84:78-89 